\title{
Commercial test kits for detection of Lyme borreliosis: a meta-analysis of test accuracy
}

\author{
Michael J Cook' \\ Basant K Puri² \\ 'Independent researcher, Dorset, \\ UK; ${ }^{2}$ Department of Medicine, \\ Hammersmith Hospital, Imperial \\ College London, London, UK
}

This article was published in the following Dove Press journal:

International Journal of General Medicine

18 November 2016

Number of times this article has been viewed
Correspondence: Michael J Cook Independent researcher, 39 Merley Drive, Highcliffe, Dorset BH23 5BN, UK Tel +44 I425270832 Emailmcook98@msn.com
Abstract: The clinical diagnosis of Lyme borreliosis can be supported by various test methodologies; test kits are available from many manufacturers. Literature searches were carried out to identify studies that reported characteristics of the test kits. Of 50 searched studies, 18 were included where the tests were commercially available and samples were proven to be positive using serology testing, evidence of an erythema migrans rash, and/or culture. Additional requirements were a test specificity of $\geq 85 \%$ and publication in the last 20 years. The weighted mean sensitivity for all tests and for all samples was $59.5 \%$. Individual study means varied from $30.6 \%$ to $86.2 \%$. Sensitivity for each test technology varied from $62.4 \%$ for Western blot kits, and $62.3 \%$ for enzyme-linked immunosorbent assay tests, to $53.9 \%$ for synthetic C6 peptide ELISA tests and $53.7 \%$ when the two-tier methodology was used. Test sensitivity increased as dissemination of the pathogen affected different organs; however, the absence of data on the time from infection to serological testing and the lack of standard definitions for "early" and "late" disease prevented analysis of test sensitivity versus time of infection. The lack of standardization of the definitions of disease stage and the possibility of retrospective selection bias prevented clear evaluation of test sensitivity by "stage". The sensitivity for samples classified as acute disease was $35.4 \%$, with a corresponding sensitivity of $64.5 \%$ for samples from patients defined as convalescent. Regression analysis demonstrated an improvement of $4 \%$ in test sensitivity over the 20 -year study period. The studies did not provide data to indicate the sensitivity of tests used in a clinical setting since the effect of recent use of antibiotics or steroids or other factors affecting antibody response was not factored in. The tests were developed for only specific Borrelia species; sensitivities for other species could not be calculated.

Keywords: test sensitivity, 2 tier test, two-tier test, ELISA test, Western Blot, test specificity

\section{The disease}

Lyme borreliosis (LB) is an arthropod-borne zoonosis caused by several species of Borrelia bacteria. It can present with a wide range of symptoms, which are common to a number of other diseases. Soon after infection, the symptoms can be nonspecific and include fatigue. A characteristic erythema migrans (EM) dermatological lesion presents sometimes soon after infection in some cases of infection. Later symptoms reflect inflammation caused to specific organs and include cognitive dysfunction, arthralgia, myalgia, neuropathy, and ophthalmic and auditory symptoms.

\section{The pathogen}

LB is caused by bacteria of the genus Borrelia, of the family Spirochaetaceae in the phylum Spirochaetes, and is named after the French physician and biologist Amédée 
Borrel (1867-1936) who worked on the classification of spirochetes and carried out studies on, in particular, Borrelia gallinarum (then named Spirillum gallinarum). ${ }^{1}$ At the time of writing, 21 species of Borrelia in the Borrelia burgdorferi sensu lato complex related to LB have been identified, many of which are known or potential pathogens to humans. ${ }^{2}$ They are adapted to be able to move between arthropod and mammalian hosts and express different outer surface proteins to avoid the immune systems of each host.

\section{Disease stages}

LB is a multisystemic infection, and dissemination from the site of a tick bite occurs rapidly by transportation of the spirochetes through the bloodstream. Invasion of specific organs and tissues may occur randomly and with no definite order of progression. Inflammation of specific organs and expression of symptoms can be dependent upon preexisting conditions. Each study assessed for the present metaanalysis classified samples into disease stages, sometimes including acute, chronic, early disseminated, early and late neurological, and early and late arthritis. There was no standard definition for any of these stages. The length of time for early and late stages was not uniformly defined and was frequently not defined at all. A discussion of LB transmission and difficulties in defining time of infection has been discussed in a prior publication by one of the authors (MJC). ${ }^{3}$

The possibility of bias resulting from the retrospective nature of the studies has been discussed in a recent analysis of both commercial and developmental test kits, including those in this analysis; all case-control studies (59 out of 59) had a high probability of bias in patient sampling and a high risk of bias in the timing and flow of the disease. ${ }^{4}$ Since there was no standardization for definitions for the disease stages, including timing for early and late disease, in the present study, the definitions provided by each author have been used together with summaries generated by combining symptoms where possible. However, because of these uncertainties, data for overall sensitivity for specific test kits and methodologies will have more validity than the data by disease stages.

\section{Test methods for detection of Borrelia infections Microscopy}

Microscopy has been the "gold standard" method for detecting and classifying bacterial infections since the father of microbiology, Antonie van Leeuwenhoek described bacteria viewed through his microscope in 1676 . The method is still widely used for the diagnosis of disease and is widely used in the field of LB research during preparation of cultures for experimental work and for the production and control of materials for use in the manufacture of antigens, and occasionally in clinical investigations. ${ }^{5}$ With culture enhancement based on a polymerase chain reaction (PCR) technique, the yield of blood cultures with microscopic detection can be increased to over $70 \% .{ }^{6}$ The method is not generally used for clinical diagnosis as it requires highly trained technicians. A new fluorescent assay has been developed that makes the method more definitive using a molecular beacon-based multiplex real-time quantitative PCR assay to detect specific bacterial species. $^{7}$

The majority of tests carried out for diagnosis of LB depend upon detecting antibodies created in response to the infection.

\section{Enzyme-linked immunosorbent assay and immunofluorescence assay}

The enzyme-linked immunosorbent assay (ELISA) is the primary test normally used to evaluate blood samples; it is used sometimes as a standalone test or as the first stage of a two-tier test. There are a number of embodiments of the basic technology used in research and commercial test kits. They are based on using native antigens derived from "whole cell" extracts, recombinant antigens, or synthetic peptides based on a conserved region of the VlsE (the variable surface antigen) of B. burgdorferi for the detection of immunoglobulins. ${ }^{8}$ The tests are quantitative and give an indication of the concentration of antibodies in the sample. The Centers for Disease Control and Prevention (CDC) recommend that an immunofluorescence assay can be used instead of an ELISA as the first test in two-tier testing for Lyme disease. This indirect method has a number of limitations compared with the ELISA and is rarely used in human diagnostic testing for LB, although it is still used in veterinary practice in a number of European countries to detect antibodies against Borrelia species. ${ }^{9}$

\section{Western blot}

A second test commonly in use is the Western blot (WB), originally developed by Towbin et al. ${ }^{10,11}$ The majority of commercial Borrelia test kits use electrophoresis to separate antigens from known positive samples across a polymer strip. This is then processed with serum samples, and Borrelia antibodies that match the antigens on the strip will bind. After incubation using a substrate that will be dyed, the antibody/antigen complex can be visualized. 
The dark bands on the strip can be compared with a standard provided by the manufacturer, and the density and scoring bands can be judged as positive if the density is greater than a reference band. There are many antibodies that can be expressed after infection with Borrelia. The probability that a given one is present and detectable by the test can be very low. Of more than 12 antibodies that can be present, the probability of detection of specific bands varies from a low of $0 \%$ to a high of $68 \% .{ }^{12}$ As a result, positive interpretation of a WB strip requires more than one band to be present. For IgG test interpretation, some manufacturers specify that five or more of 10 critical bands must be positive for the test to be considered positive. Guidelines for IgM tests usually require that two or more bands are positive; however, a modified MiQ 12 2000 standard for Germany required only one IgM band for a positive diagnosis. ${ }^{13}$ There have been attempts to standardize bands and proposals to increase the sensitivity. ${ }^{14}$ Another adaptation of the technology uses antigens that are printed in strips on the polymer substrates, which are then reacted with patient serum and are more easily read manually or using a scanning densitometer. The selection of optical density thresholds is empirical and governed by the need to avoid cross-reactivity with other diseases while attempting to maintain a viable sensitivity. Variations of electroblotting include double blotting, pressure double blotting, electro-double blotting, slice blotting, tissue printing, native electrophoresis and Western blot (NEWeB), grid-immunoblotting, multiple antigen blot assay, multiple tissue WB, dot-immunobinding assay, the use of polymer immunocomplexes, blotting from PhastGel via ultrasound, and Eastern blotting. ${ }^{15}$ The WB kits are used as standalone tests or as the second stage of the two-tier protocol.

Selection of Borrelia species for extraction of antigens is based on "local" sources and a limited number of species. Test kits used in the USA typically use antigens from the B31 strain of B. burgdorferi sensu stricto, whereas those in Europe usually also include antigens derived from Borrelia afzelii and Borrelia garinii.

There are now at least nine species assigned to the LB group that are actual or probable pathogens. ${ }^{5,16-20}$ Sensitivity of WB tests is known to vary depending on the species present in the sample. One study indicates that when an in-house test was prepared from local Borrelia species, the test was significantly more sensitive than a commercial test kit in use in that region. ${ }^{21}$ No published studies have been identified that characterize the sensitivity of commercial tests for species other than those included by the manufacturer.

\section{Two-tier testing}

At a meeting held by the Association of State and Territorial Public Health Laboratory Directors in 1994, the CDC adopted a two-step methodology for defining LB cases for epidemiological studies. ${ }^{22}$ This requires a first-stage ELISA or immunofluorescence assay, and positive and equivocal samples are then tested using a WB confirmatory test (IgM and IgG WB if signs or symptoms have been present for up to 30 days [inclusive]; IgG WB if signs or symptoms have been present for more than 30 days). This was designed to standardize the methodology for testing and reporting LB throughout the USA and to minimize false positives. During one of the workshop sessions at this meeting, this methodology was recommended for diagnostic testing in clinical cases ${ }^{22}$ and has been widely accepted for that use, including by the Infectious Diseases Society of America, British Infection Association, European Union Concerted Action on Lyme Borreliosis, and many others. ${ }^{23-25}$

\section{Polymerase chain reaction}

This technique is based on direct detection of DNA by amplification of small quantities of DNA fragments from a sample and comparison with a known DNA sequence. ${ }^{26,27}$ There are a number of modifications including quantitative PCR and real-time PCR. The test is moving out of the research laboratory into use to support clinical diagnosis. The search profiles did not identify any independent evaluation data. Some are shown in this analysis for comparison, but not included in the calculations of overall test sensitivities.

\section{New testing technologies}

There are a number of tests currently in use by laboratories for detecting LB infections that do not use antibody detection, including the enzyme-linked immunospot, lymphocyte transformation test, and culture-enhanced microscopy. These are based on detecting immune system activation or direct visualization of the bacteria. Another identifies Borrelia DNA fragments using electrospray ionization mass spectrometry, and others are in development.

There is preliminary evidence suggesting that newer technologies might have some advantages. For example, in a study of 54 consecutively presenting patients carried out by one of the authors (BKP), while 45 had negative WB results by the CDC criteria, 19 (42\%) of these patients were positive according to the lymphocyte transformation test-memory lymphocyte immunostimulation assay. ${ }^{28}$ None of these newer tests is included in this analysis owing to a lack of sufficient independent studies of sensitivity and specificity at the time of preparation of this manuscript. 


\section{Study selection}

PubMed and Google Scholar were used with the search terms "Lyme disease OR borreliosis AND testing" to identify studies. All papers published since 1995 were selected for consideration. Data analysis and charting were carried out using software based on the Microsoft Excel platform. ${ }^{29}$

The studies were separated into two groups:

\section{Group I}

Studies were included in the analysis where the following criteria were met:

1. Samples were proven to be positive for LB based on one or more of the following: clinical records of an EM rash; positive serology; culture; samples meeting the CDC criteria (generally being an EM rash or being two-tier positive) or CDC-certified panels with samples characterized by them as positive, negative, or equivocal. Full criteria are available for your reference in Centers for Disease Control and Prevention. ${ }^{30}$

2. The tests were commercially available.

3. The specificity was $\geq 85 \%$.

These are shown in Table 1 with test method, sample type/ disease stage, and performance. ${ }^{31-47}$

\section{Group 2}

Studies were excluded where one or more the inclusion criteria was absent.

These are given in detail in Table 2 which includes performance data and the reasons for exclusion. They included studies that used in-house developed tests or experimental interpretation methodologies, those where samples were from patients with suspected LB but not definitively proven, where there were no specificity data, and one study where interpretation criteria were modified from the manufacturers' specified method were all excluded. ${ }^{28,48-74}$

Some studies included a mixture of samples, with some meeting Group 1 inclusion criteria, and other samples selected based on clinical symptoms alone. For example, Porwancher et $\mathrm{al}^{41}$ used acute and convalescent samples that were from culture-confirmed cases, and later-stage samples based solely on clinical symptoms. In such cases, only data meeting Group 1 criteria were included.

\section{Sensitivity and specificity}

The most important parameters that define the characteristics of a test are the sensitivity, which is the probability that a positive sample will be defined as positive by the test, and specificity, the probability that a negative sample will be defined as negative, usually defined as 1 - (false positive probability).

In antibody tests, there is a relationship between sensitivity and specificity as described by the receiver operating curve. As a test is made more specific, the sensitivity decreases and vice versa. This is important in the context of the studies selected in this analysis. It is possible to increase the sensitivity of a test by lowering detection thresholds; however, in doing so, the probability of false positives increases. There are many process parameters that affect the sensitivity of ELISA and WB tests including serum dilution, WB incubation times, WB antigen concentration, band selection, etc.

Where the kits provided by the manufacturer had separate $\operatorname{IgM}$ and $\operatorname{IgG}$ antibody tests, the highest sensitivity reported was used to determine study means. In some studies, the sensitivity based on either IgM or IgG antibody detection was reported, and this value was used.

Specificity data are those reported by the researchers. In some cases, the specificity was determined using blood donor samples from healthy people in LB endemic areas, in some cases from donors in areas where LB was nonendemic (for example, Branda et al), ${ }^{33}$ whereas in other cases, controls included samples from patients with known diseases that could cross-react with the test kits. Engstrom et al, ${ }^{54}$ for example, included a small group of samples from patients who had been diagnosed with other diseases including Epstein-Barr viral infection, syphilis, rheumatoid arthritis, multiple sclerosis, leptospirosis, systemic lupus erythematosus, group A streptococcal infection, and relapsing fever. The possibility exists that samples from patients with LB were included in the groups used to determine specificity. For example, many studies indicate that healthy controls from general populations and at-risk groups are seropositive for $\mathrm{LB}^{75,76}$ and that blood donor samples contain significant numbers that are seropositive. ${ }^{77,78}$ This could result in unnecessary desensitization of tests to meet specificity targets.

\section{Data extraction and analysis}

There was no standardized method for carrying out the evaluations or recording data, and so data were extracted manually from the documents and entered into Microsoft Excel worksheets. This allowed computation and preparation of a standard format giving sample size, positive samples, and percentage of positive results. This was used to define the sensitivity for each stage of disease and for each test method. To compute the overall sensitivity for all studies and for all subgroups, the weighted average of sample size and positive samples of subgroups was used. 
Table I Studies included in the analysis

\begin{tabular}{|c|c|c|c|c|c|c|c|c|c|c|}
\hline Study & Year & $\begin{array}{l}\text { Patient } \\
\text { enrollment }\end{array}$ & $\begin{array}{l}\text { Disease } \\
\text { stage }\end{array}$ & Test & $\begin{array}{l}\text { Mean of } \\
\text { subgroup } \\
\text { positives }\end{array}$ & $\begin{array}{l}\text { Subgroup } \\
\text { sample } \\
\text { size }\end{array}$ & Sens & Spec & $\begin{array}{l}\text { Number } \\
\text { of test } \\
\text { kits }\end{array}$ & Comment \\
\hline Bacon et $\mathrm{al}^{31}$ & 2003 & CDC & All & Two-tier & 186.3 & 280 & $66 \%$ & $99 \%$ & 8 & $\begin{array}{l}\text { Multiple samples } \\
\text { from some subjects. Only } \\
\text { IgM result included. IgG } \\
\text { sensitivity was } 31 \% \text {. }\end{array}$ \\
\hline Klempner et $\mathrm{a}^{37}$ & 2001 & CDC & Chronic & WB IgG & 14.0 & 21 & $67 \%$ & $100 \%$ & I & \\
\hline Mogilyansky et al ${ }^{40}$ & 2004 & CDC panel & All & WB & 14.3 & 18 & $79 \%$ & $89 \%$ & 7 & $\begin{array}{l}\text { C6 data excluded with } \\
\text { specificity of } 73 \% \text {. }\end{array}$ \\
\hline Tilton et $\mathrm{al}^{43}$ & 1997 & CDC panel & All & WB & 30.7 & 46 & $67 \%$ & $\begin{array}{l}\text { Note } \\
\text { I }\end{array}$ & 6 & $\begin{array}{l}\text { Test runs with low } \\
\text { specificity }(60.0 \%, 68.2 \%) \\
\text { excluded. }\end{array}$ \\
\hline Smit et $\mathrm{al}^{42}$ & 2015 & Seropositive & All & $\lg M / \operatorname{lgG}$ & 8.5 & 21 & $40 \%$ & $99 \%$ & 4 & \\
\hline Branda et $\mathrm{al}^{33}$ & 2010 & CDC/EM & All & $\begin{array}{l}\text { EIA/WB/ } \\
\text { two-tier }\end{array}$ & 28.2 & 45 & $69 \%$ & $98 \%$ & 3 & \\
\hline Wormser et $\mathrm{al}^{47}$ & 2012 & $\begin{array}{l}\text { EM and/or } \\
\text { seropositive }\end{array}$ & $\mathrm{EM}$ & Two-tier & 83.0 & 158 & $53 \%$ & $99 \%$ & 5 & $\begin{array}{l}\text { Only two-tier results } \\
\text { included. ELISA test } \\
\text { "indeterminate" was } \\
\text { included with "positive" } \\
\text { results for WB. }\end{array}$ \\
\hline Dessau $^{81}$ & 2013 & CSF positive & $\begin{array}{l}\text { Neuro- } \\
\text { borreliosis }\end{array}$ & ELISA & 37.0 & 48 & $69 \%$ & $97 \%$ & 2 & $\begin{array}{l}\text { CSF-positive samples. IgG } \\
\text { data only used. }\end{array}$ \\
\hline Branda et $\mathrm{al}^{34}$ & 2013 & $\begin{array}{l}\text { EM/culture/ } \\
\text { seropositive }\end{array}$ & All & $\begin{array}{l}\text { ELISA, } \\
\text { C6, WB }\end{array}$ & 51.3 & 64 & $80 \%$ & $99 \%$ & 8 & $\begin{array}{l}\text { Data for European } \\
\text { samples tested with US } \\
\text { B3I test kits not included }\end{array}$ \\
\hline Goossens et $\mathrm{a}^{36}$ & 1999 & EM & EM & $\begin{array}{l}\text { ELISA, } \\
\text { WB }\end{array}$ & 13.9 & 26 & $48 \%$ & $88 \%$ & 15 & $\begin{array}{l}\text { Only IgM result included. } \\
\text { IgG sensitivity was lower } \\
\text { at } 16 \%\end{array}$ \\
\hline Johnson et $\mathrm{a}^{80}$ & 1996 & EM & All & Two-tier & 37.1 & 58 & $64 \%$ & $96 \%$ & 2 & $\begin{array}{l}\text { Only two-tier study } \\
\text { included. See excluded } \\
\text { studies. }\end{array}$ \\
\hline Tjernberg et $\mathrm{a}^{44}$ & 2007 & EM & Acute & ELISA, C6 & 55.8 & 158 & $35 \%$ & $87 \%$ & 3 & \\
\hline Trevejo et a ${ }^{45}$ & 1999 & EM & All & Two-tier & 37.0 & $12 \mid$ & $31 \%$ & $100 \%$ & 3 & \\
\hline Binnicker et al ${ }^{32}$ & 2008 & $\begin{array}{l}\text { EM and/or } \\
\text { culture }\end{array}$ & All & WB IgM & 16.3 & 28 & $58 \%$ & $95 \%$ & 4 & \\
\hline $\begin{array}{l}\text { Gomes-Solecki } \\
\text { et } \mathrm{al}^{35}\end{array}$ & 2002 & $\begin{array}{l}\text { EM and } \\
\text { culture positive }\end{array}$ & EM & ELISA & 56.0 & 65 & $86 \%$ & $100 \%$ & 2 & $\begin{array}{l}\text { Only commercial test } \\
\text { included and only } \\
\text { samples with clear } \\
\text { definition of status of } \\
\text { sample. }\end{array}$ \\
\hline Marangoni et $\mathrm{a}^{38}$ & 2005 & Culture & EM & ELISA, C6 & 27.7 & 45 & $40 \%$ & $90 \%$ & 5 & $\begin{array}{l}\text { Data are for samples at } \\
\text { enrollment. Follow-up } \\
\text { data not included. }\end{array}$ \\
\hline Marangoni et a ${ }^{39}$ & 2008 & Culture & All & ELISA & 44.0 & 66 & $67 \%$ & $97 \%$ & 4 & \\
\hline Porwancher et al ${ }^{41}$ & 2011 & Culture & All & All & 45.3 & 80 & $57 \%$ & $96 \%$ & 4 & $\begin{array}{l}\text { Best-case WB and two- } \\
\text { tier selected. }\end{array}$ \\
\hline
\end{tabular}

Notes: Enrollment criteria - CDC: samples met CDC criteria; EM rash and/or seropositive: using a two-tier test with approved test kits; EM: samples from patients with documentation of EM rash in clinical records; culture: samples were positive using culture and microscopy; CDC panel: samples obtained from the CDC and certified to meet the criteria defined.

Abbreviations: sens, weighted mean test sensitivity; spec, test specificity; WB, Western blot; EM, erythema migrans; CDC, Centers for Disease Control and Prevention; EIA, immunofluorescence assay; ELISA, enzyme-linked immunosorbent assay; CSF, cerebrospinal fluid; C6, synthetic C6 peptide ELISA. 
Table 2 Studies not meeting inclusion criteria

\begin{tabular}{|c|c|c|c|c|c|c|c|}
\hline Study & Year & $\begin{array}{l}\text { Patient } \\
\text { enrollment }\end{array}$ & Disease stage & Test & Sens & Spec & Comment \\
\hline Ang et al ${ }^{48}$ & 2011 & Clinical & All & ELISA, VlsE, C6 & $44 \%$ & $86 \%$ & Samples from patients with suspected Lyme disease. \\
\hline Burbelo et $\mathrm{al}^{49}$ & 2010 & Clinical & All & $\begin{array}{l}\text { VOVO, C6, } \\
\text { ELISA }\end{array}$ & $98 \%$ & $99 \%$ & In-house developed test. \\
\hline Busson et $\mathrm{a}^{50}$ & 2012 & & All & $\begin{array}{l}\text { ELISA, WB, } \\
\text { two-tier }\end{array}$ & $98 \%$ & $91 \%$ & $\begin{array}{l}\text { Samples from patients with suspected Lyme } \\
\text { disease. Duplicate samples from patients. Kits } \\
\text { supplied by manufacturers. }\end{array}$ \\
\hline Coulter et $\mathrm{al}^{51}$ & 2005 & Suspected & All & ELISA & $45 \%-72 \%$ & ND & $\begin{array}{l}\text { No specificity data. Study of culture sensitivity } \\
\text { and algorithm using culture plus PC. }\end{array}$ \\
\hline Craven et al ${ }^{52}$ & 1996 & CDC & All & ELISA/WB & $57 \%-100 \%$ & $71 \%-98 \%$ & $\begin{array}{l}\text { In-house tests. Work carried out in 1992, tests } \\
\text { not commercially available. Interlaboratory } \\
\text { study. Cross-reactive samples not used for } \\
\text { some specificity characterization. }\end{array}$ \\
\hline Dessau et $\mathrm{a}^{53}$ & 2010 & Clinical & All & $\begin{array}{l}\text { ELISA local } \\
\text { antigens }\end{array}$ & $9.2 \%$ & ND & $\begin{array}{l}\text { Data are best-case lgM tests. } \lg G \text { was lower } \\
\text { sensitivity, specificity was } 98 \% \text {. }\end{array}$ \\
\hline Engstrom et $\mathrm{al}^{54}$ & 1995 & $\begin{array}{l}\text { EM } \\
\text { documented }\end{array}$ & Early and EM & In house & $43 \%$ & $97 \%$ & Test development. \\
\hline Eshoo et $\mathrm{al}^{55}$ & 2012 & $\mathrm{EM} / \mathrm{CDC}$ & All & PCR/EIS-MS & $62 \%$ & $100 \%$ & PCR ESI-MS. \\
\hline Goettner ${ }^{56}$ & 2005 & EM & Early & Western blot & $81 \%$ & $99 \%$ & In-house developed test. \\
\hline Heikkilä et al $\left.\right|^{58}$ & 2003 & Seropositive & Arthritis & ELISA & $37 \%-96 \%$ & ND & $\begin{array}{l}\text { Results from experiments with eleven different } \\
\text { antigens. }\end{array}$ \\
\hline Johnson et $\mathrm{al}^{80}$ & 1996 & Clinical & All & $\begin{array}{l}\text { Culture/two- } \\
\text { tier }\end{array}$ & $81 \%$ & $90 \%$ & Possible sample bias described by authors. \\
\hline Koidl et a ${ }^{59}$ & 2013 & Clinical & All & $\lg M$ & $32 \%$ & ND & Samples from patients with suspected Lyme disease. \\
\hline Lawrenz et $\mathrm{al}^{61}$ & 1999 & All & EM & ELISA & $70 \%$ & $98 \%$ & In-house developed test. \\
\hline Liang et $\mathrm{al}^{8}$ & 1999 & Seropositive & All & C6 & $89 \%$ & $99 \%$ & In-house developed test. \\
\hline Liang et $\mathrm{a}^{60}$ & 2000 & All & All & $\mathrm{C} 6$ & $84 \%$ & $99 \%$ & In-house developed test. \\
\hline Liu et $\mathrm{a}^{62}$ & 2013 & All & All & ELISA, WIB & $67 \%$ & $94 \%$ & In-house developed test. \\
\hline Nordberg et a ${ }^{63}$ & 2012 & $\begin{array}{l}\text { Well } \\
\text { characterised }\end{array}$ & Neuroborreliosis & Elispot & $36 \%$ & $82 \%$ & $\begin{array}{l}\text { Samples from patients with suspected Lyme } \\
\text { disease. }\end{array}$ \\
\hline $\begin{array}{l}\text { Nowakowski } \\
\text { et al }{ }^{64}\end{array}$ & 2001 & $\mathrm{EM} / \mathrm{CDC}$ & EM & Culture & $48 \%$ & ND & Culture test not commercially available. \\
\hline $\begin{array}{l}\text { Nowakowski } \\
\text { et al }{ }^{64}\end{array}$ & 2001 & $\mathrm{EM} / \mathrm{CDC}$ & EM & PCR & $72 \%$ & ND & PCR tests not generally available. \\
\hline $\begin{array}{l}\text { Nowakowski } \\
\text { et al }\end{array}$ & 2001 & $\mathrm{EM} / \mathrm{CDC}$ & EM & Two-tier & $68 \%$ & ND & Specificity not determined in the study. \\
\hline Puri et $\mathrm{al}^{28}$ & 2014 & Clinical & $\begin{array}{l}\text { Consecutive } \\
\text { presentation }\end{array}$ & LTT MELISA & ND & ND & $\begin{array}{l}\text { Study compared WB and LTT test results. } \\
\text { Absolute sensitivity and specificity were not } \\
\text { investigated. }\end{array}$ \\
\hline Rebman et $a^{65}$ & 2015 & $\mathrm{EM}$ rash $>5 \mathrm{~cm}$ & EM & All & $41 \%$ & ND & Commercial laboratory. No data for specificity. \\
\hline $\begin{array}{l}\text { Robertson } \\
\text { et al }\end{array}$ & 2000 & EM or Clinical & All & $\begin{array}{l}\text { Unspecified } \\
\text { WB }\end{array}$ & $19 \%-100 \%$ & $44 \%-100 \%$ & $\begin{array}{l}\text { 2-, 3-, and 4-band interpretation criteria, not } \\
5 \text { band. }\end{array}$ \\
\hline Ryffel et al ${ }^{67}$ & 1999 & Seropositive & All & WB & ND & ND & Protein-based study for Borrelia species. \\
\hline $\begin{array}{l}\text { Schulte-Spectel } \\
\text { et al }{ }^{68}\end{array}$ & 2003 & Seropositive & Neuro & $\begin{array}{l}\text { Whole cell } \\
\text { blot }\end{array}$ & $86 \%$ & $86 \%$ & Test development. \\
\hline Seriburi et a ${ }^{69}$ & 2012 & Clinical & All & two-tier & ND & ND & $\begin{array}{l}\text { False-positive study of clinical cases. No } \\
\text { sensitivity data. }\end{array}$ \\
\hline Skarpaas et $\mathrm{al}^{70}$ & 2007 & Definite LNB & Neuro & Quick C6 Sera & $98 \%$ & $61 \%$ & Excluded for low specificity (61\% with serum). \\
\hline Skogman et al ${ }^{71}$ & 2008 & CSF positive & NB & ELISA & $82 \%$ & $100 \%$ & Only data for in-house test is available. \\
\hline Smismans et al ${ }^{72}$ & 2006 & Seropositive & All & Study mean & $77 \%$ & $84 \%$ & $\begin{array}{l}\text { Borderline results counted positive. Specificity } \\
\text { less than } 85 \% \text {. }\end{array}$ \\
\hline Steere et $\mathrm{al}^{73}$ & 2008 & CDC/EM & All & C6/two-tier & $45 \%$ & $100 \%$ & First-stage test was in-house ELISA. \\
\hline Vermeesch et a $\left.\right|^{46}$ & 2009 & Seropositive/CSF & Neurological & C6 & $68 \%$ & ND & No specificity data. \\
\hline Wormser et $\mathrm{al}^{74}$ & 2008 & CDC/EM & All & C6/two-tier & $69.5 \% / 38.9 \%$ & ND & No specificity data. \\
\hline Wormser et a $\left.\right|^{47}$ & 2012 & EM & All & All & $53 \%$ & ND & No specificity data. \\
\hline Study mean & & & & & $69.3 \%$ & $91.5 \%$ & Specificity mean based on limited reported data. \\
\hline
\end{tabular}

Abbreviations: ESI-MS, electrospray ionization mass spectrometry; sens, weighted mean test sensitivity; spec, test specificity; WB, Western blot; EM, erythema migrans; CDC, Centers for Disease Control and Prevention; ELISA, enzyme-linked immunosorbent assay; CSF, cerebrospinal fluid; PCR, polymerase chain reaction; LTT, lymphocyte transformation test; LNB, Lyme neuroborreliosis; ND, not determined; C6, synthetic C6 peptide ELISA. 


\section{Results and discussion}

A summary of the tests, including sensitivity and specificity data, is shown in Figures 1-5 and Tables 3 and 4. Included are the sample sources, disease stage and test methods used, and the sensitivity confidence intervals.

The weighted mean sensitivity for all studies and for all disease stages is $59.5 \%$, and the weighted mean specificity is $96.1 \%$. In comparison, the mean sensitivity of the excluded Group 2 studies was 69.3\%; however, 13 studies did not report specificity data, and others demonstrated specificities as low as $61.5 \%$. Low specificity is associated with increased test sensitivity.

The mean sensitivity for individual studies varied from a low of $30.6 \%$ (Trevejo et $\mathrm{al}^{45}$ ) to a high of $80.2 \%$ (Mogilyansky et $\left.\mathrm{al}^{40}\right)$. The lowest sensitivity for a specific test was $7.4 \%$ (Branda et $\mathrm{al}^{33}$ ). This was a WB test used to identify IgG antibodies in samples defined by the authors as acute stage.

The most sensitive test methodology was WB with a weighted mean of studies of $62.4 \%$, and varied from a low of $53.5 \%$ to a high of $76.6 \%$. The weighted mean of all ELISA tests was $62.3 \%$, which was not statistically different from the WB test, with a low of $45.0 \%$ and a high of $82.2 \%$. The mean sensitivity of the six studies using synthetic C6 peptide
ELISA tests was $53.9 \%$, with a low of $42.1 \%$ and a high of $53.9 \%$. Finally, the mean of the two-tier tests was $53.7 \%$, with a low of $38.9 \%$ and a high of $67.5 \%$. These data are shown in Table 3 and Figures 3-6.

Studies were excluded where the specificity was $<85 \%$. Four studies were excluded based on this. Smismans et $\mathrm{al}^{72}$ was excluded as the study mean specificity was $74 \%$ and sensitivity was $77 \%$. High specificity was obtained using a two-tier test with the first-stage test optical density threshold lowered. Nordberg et $\mathrm{al}^{63}$ was excluded as this study had a specificity of $82 \%$; the sensitivity was also low at $36 \%$ and would have depressed the study mean sensitivity. Craven et al's ${ }^{52}$ study had a low specificity of $71 \%$ with a sensitivity of $51 \%$, which would not significantly bias the overall results of this study. Finally, Skarpaas et al's ${ }^{70}$ study demonstrated a high sensitivity of $98 \%$ but a very low specificity of $61 \%$, which if used would lead to very high levels of false positives.

It is frequently stated that IgM antibody levels will be higher in early-stage disease and IgG antibody levels will be higher in later-stage disease. This was not always supported by the data. Branda et $\mathrm{al}^{34}$ reported a sensitivity of an IgM test as $80 \%$ for neuroborreliosis with the corresponding IgG test having a sensitivity of $60 \%$. Some studies did demonstrate

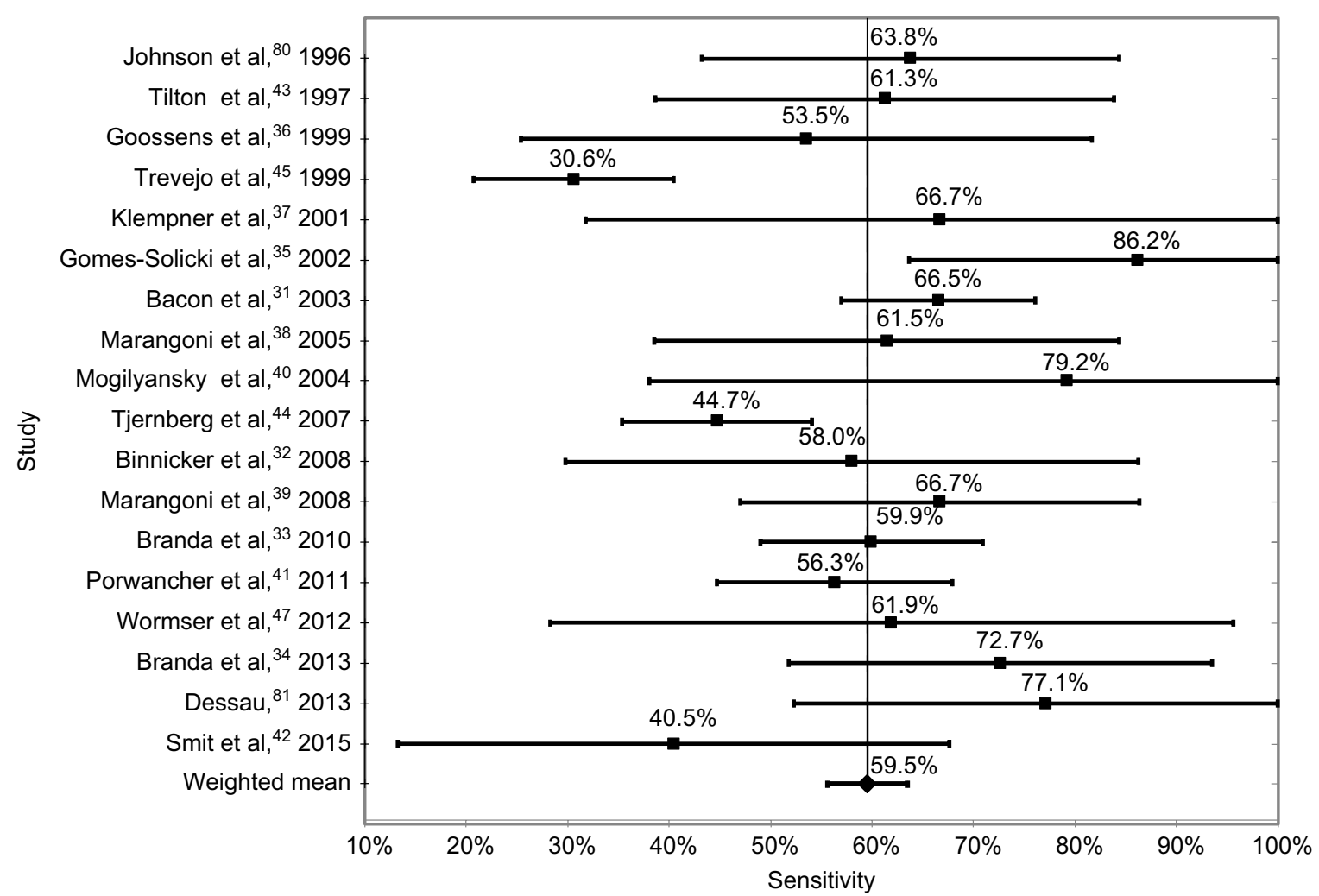

Figure I Studies included in the analysis. Weighted sensitivity for each study. 


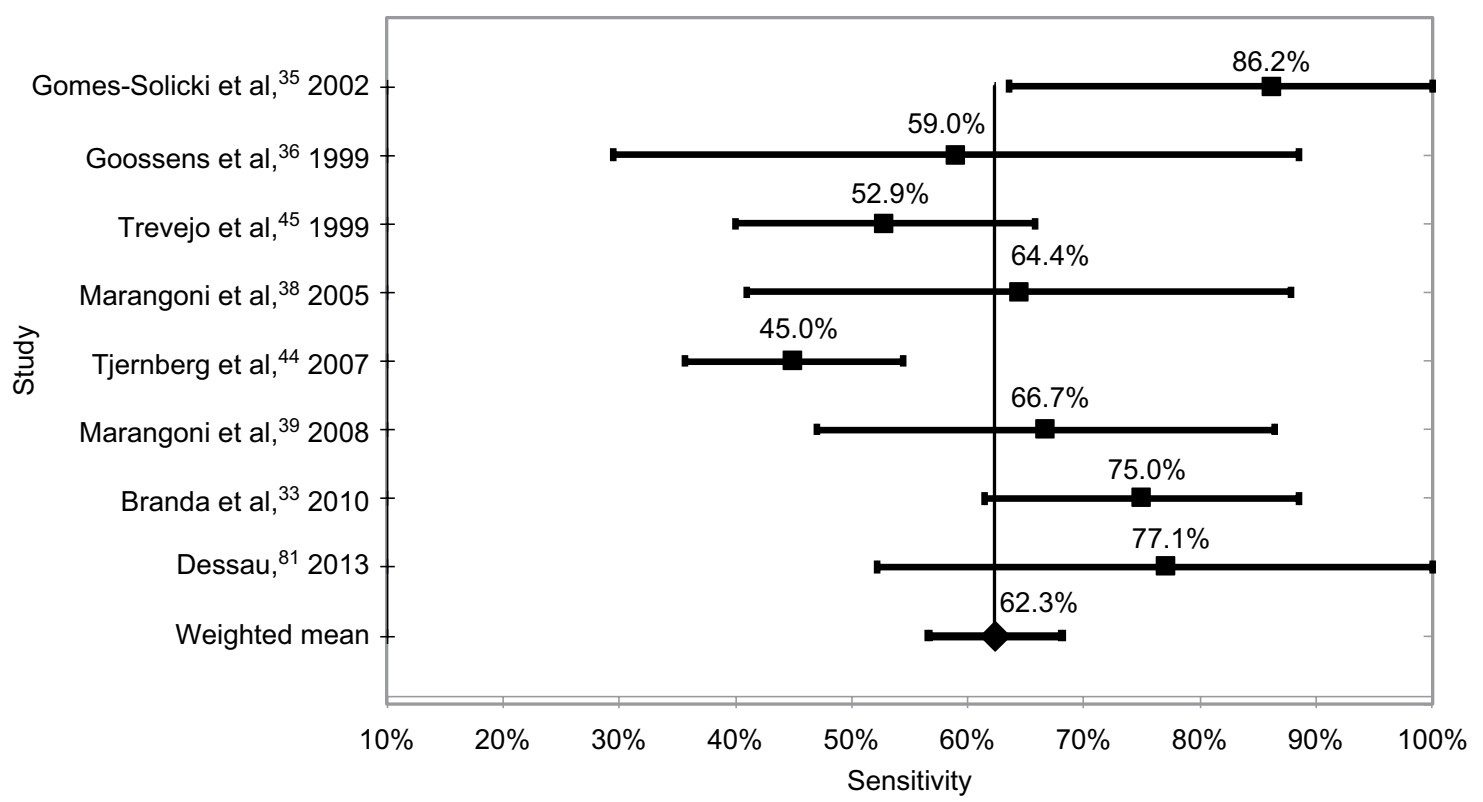

Figure 2 ELISA sensitivity.

Abbreviation: ELISA, enzyme-linked immunosorbent assay.

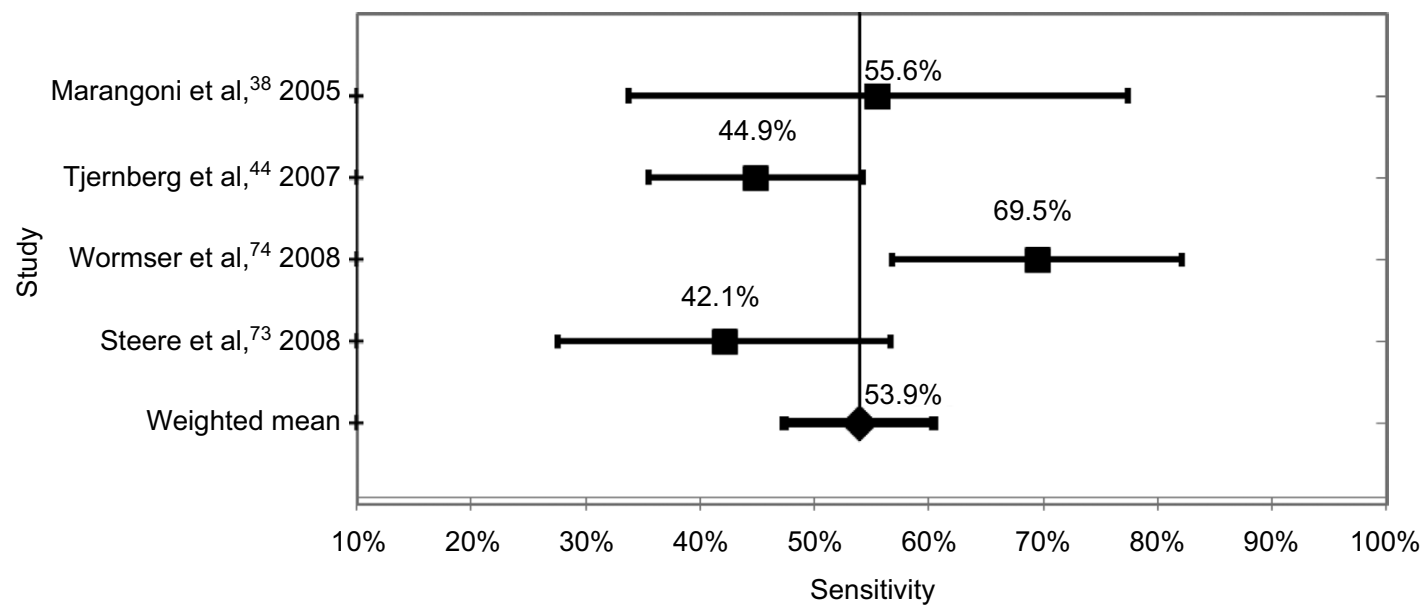

Figure 3 Synthetic C6 peptide ELISA test sensitivity.

Abbreviation: ELISA, enzyme-linked immunosorbent assay.

a higher sensitivity for IgM tests with early-stage disease, for example, Goossens et $\mathrm{al}^{36}$ showed IgM sensitivity of $59 \%$ and IgG sensitivity of $48 \%$ using a whole-cell ELISA, and IgM sensitivity of $48 \%$ and $\operatorname{IgG}$ of $15.5 \%$ using a WB test. However, Bacon et $\mathrm{al}^{31}$ reported a sensitivity of $43.8 \%$ with acute stage disease using an IgG test and $18.8 \%$ using an IgM test, and Liu et al ${ }^{62}$ for early-stage EM rash samples showed an IgG test sensitivity of $78.8 \%$, much higher than the IgM test at $57.7 \%$.

Some studies defined a positive result based on either an IgM or an IgG response, whereas others reported sensitivity based on a single test, IgM or IgG. There was a significantly higher test sensitivity when the IgM and $\operatorname{IgG}$ positives were combined. Branda et $\mathrm{al}^{34}$ found that the sensitivity of a WB test was $53.1 \%$ based on IgM response, $67.2 \%$ for an $\operatorname{IgG}$ response, and $81.3 \%$ when either the IgM or IgG response was used.

In the case of early-stage disease where there was a record of an EM rash, the sensitivity based on IgM was 35\%, 35\% for an IgG response, and 55\% for combined IgM or IgG response. Similarly, for later-stage neuroborreliosis, the sensitivity for $\operatorname{IgM}$ was $80 \%$, for $\operatorname{IgG} 60 \%$, and for combined IgM or IgG $87 \%$. Marangoni et al ${ }^{38}$ demonstrated for culture confirmed samples an IgM sensitivity of $67 \%$, for IgG $33 \%$, and for combined IgM or IgG $71 \%$.

These results indicate that laboratories where the selection of an $\operatorname{IgM}$ or IgG test is based on clinical records that suggest early- or late-stage disease have a lower sensitivity 


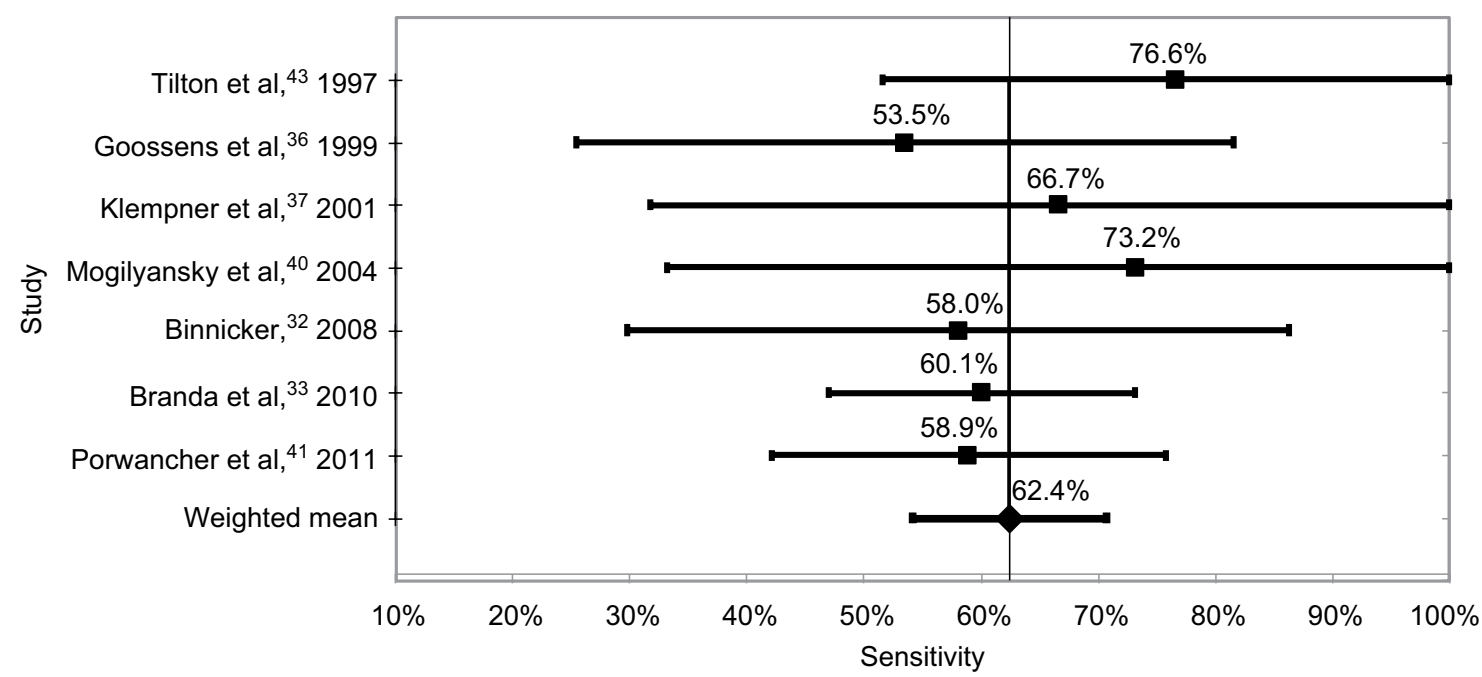

Figure 4 Western blot test sensitivity.

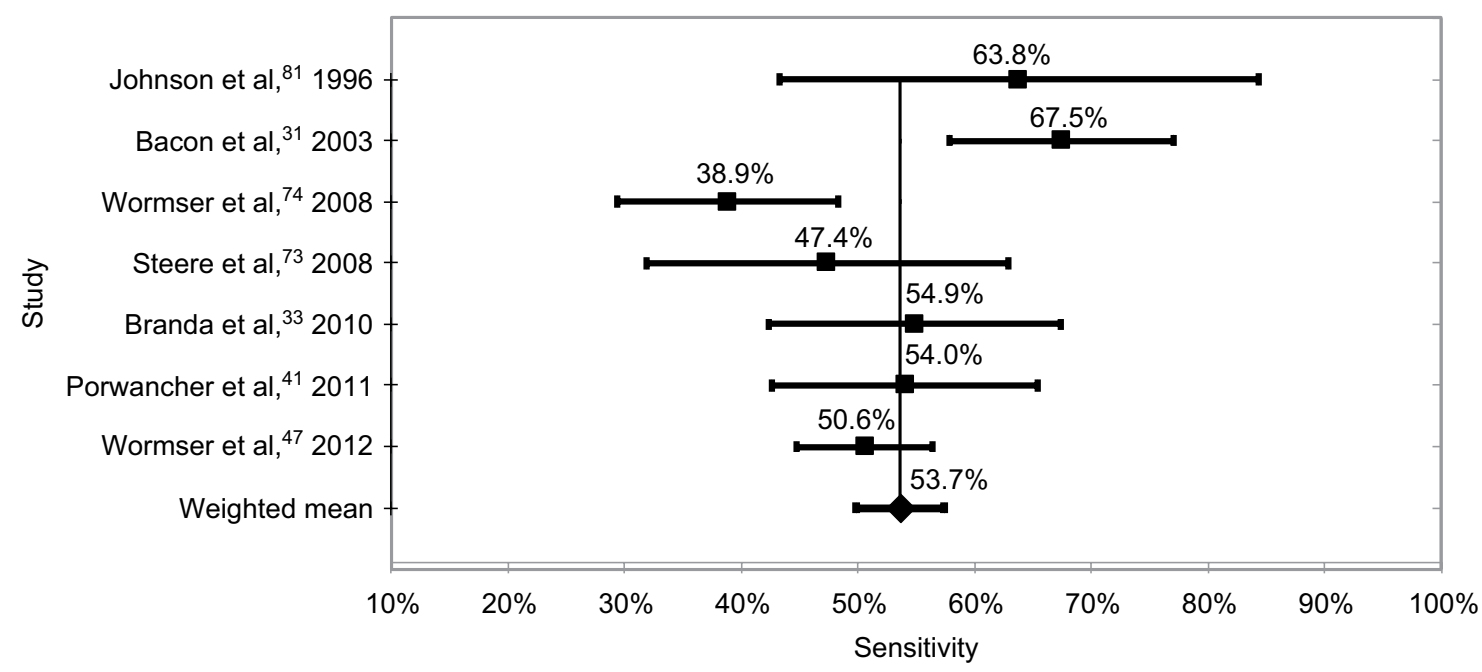

Figure 5 Two-tier sensitivity test.

Table 3 Test sensitivity summary

\begin{tabular}{lll}
\hline Test method & Sensitivity & $\mathbf{9 5 \%} \mathbf{C l}$ \\
\hline ELISA & $62.3 \%$ & $56.6 \%-68.1 \%$ \\
C6 & $53.9 \%$ & $48.3 \%-61.1 \%$ \\
Western Blot & $62.4 \%$ & $54.2 \%-70.7 \%$ \\
Two-tier & $53.7 \%$ & $49.9 \%-57.4 \%$ \\
ALL & $59.5 \%$ & $55.6 \%-63.5 \%$ \\
\hline
\end{tabular}

Abbreviations: ELISA, enzyme-linked immunosorbent assay; C6, synthetic C6 peptide ELISA; Cl, confidence interval; WB, Western blot.

Table 4 Test sensitivity for disease stage

\begin{tabular}{lll}
\hline Disease stage & Sensitivity & $\mathbf{9 5 \%} \mathbf{C l}$ \\
\hline EM & $46.5 \%$ & $41.1 \%-51.9 \%$ \\
Acute/early & $35.4 \%$ & $30.5 \%-40.2 \%$ \\
Convalescent & $64.5 \%$ & $57.3 \%-71.7 \%$ \\
Neurological & $87.3 \%$ & $71.4 \%-97.5 \%$ \\
Arthritis & $95.8 \%$ & $81.8 \%-100.0 \%$ \\
Neurological/arthritis & $92.2 \%$ & $78.4 \%-100.0 \%$ \\
\hline
\end{tabular}

Abbreviations: $\mathrm{Cl}$, confidence interval; $\mathrm{EM}$, erythema migrans. than those running both tests and accepting either test as indicative of disease.

Within the limits already discussed regarding the lack of definitions and standardization of disease stage and the high risk of bias in all studies, the tests were most sensitive at $89.7 \%$ when neurological and/or arthritic symptoms were present. The sensitivity for samples from patients at the convalescent stage of the disease was $64.5 \%$, and the sensitivity for samples at the acute stage was $35.4 \%$. It should be noted that these results are based on samples that were defined as positive by the definitive existence of an EM rash, culture of Borrelia, or positive with a prior serology test, or combinations of these. These data and confidence intervals are shown in Table 4 and Figures 6-8.

The lack of antibody response in early-stage disease is well recognized by the main guidelines, all of which define 


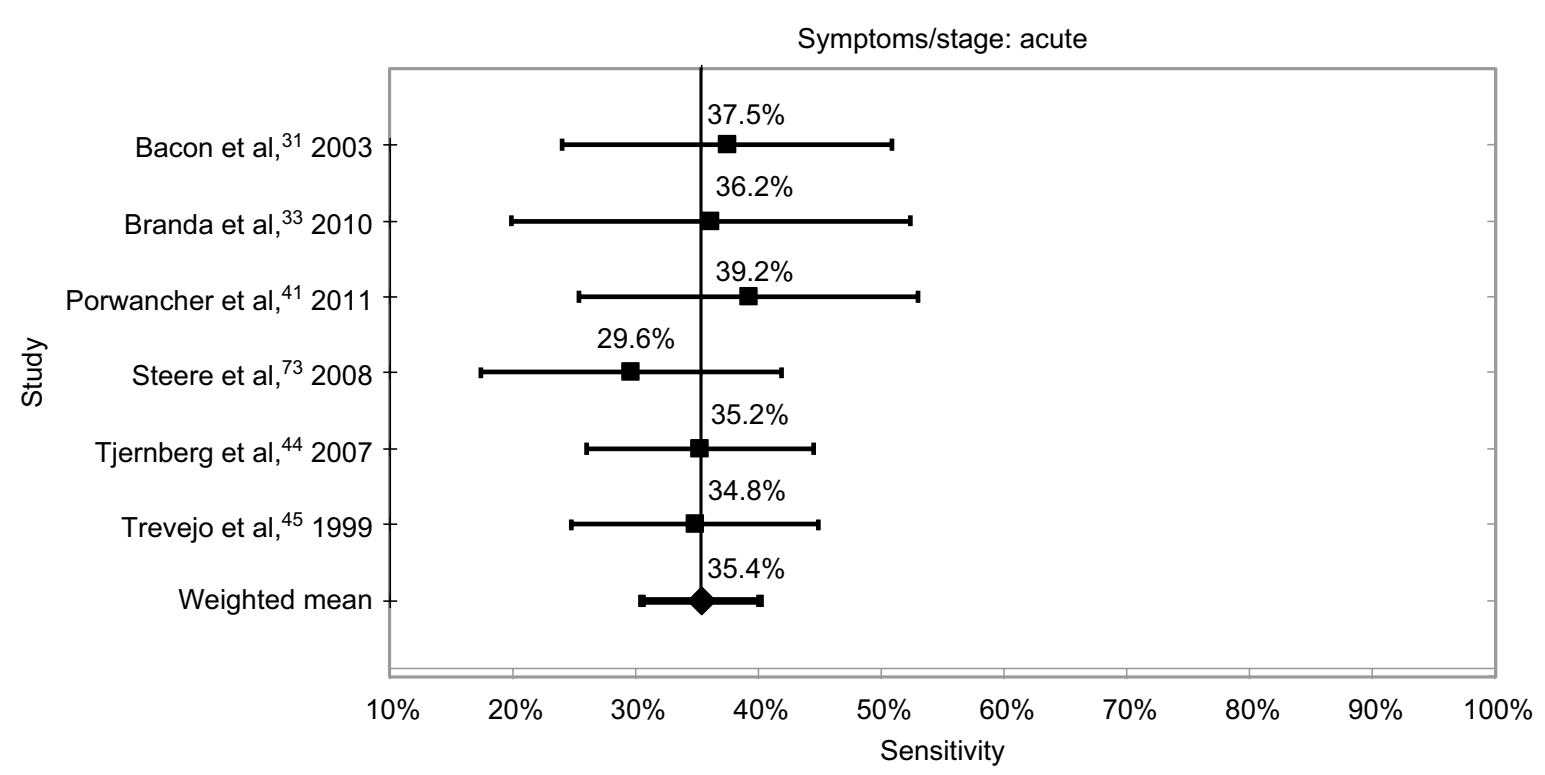

Figure 6 Sensitivity for acute stage samples.

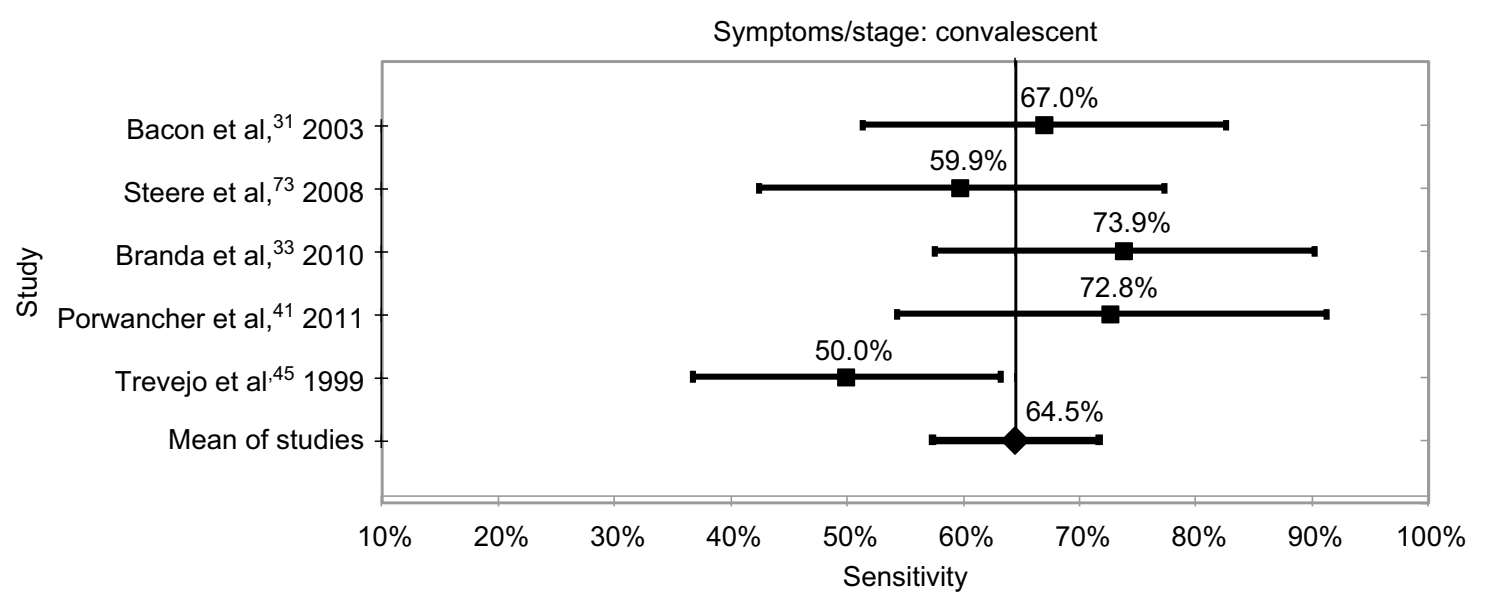

Figure 7 Sensitivity of convalescent samples.

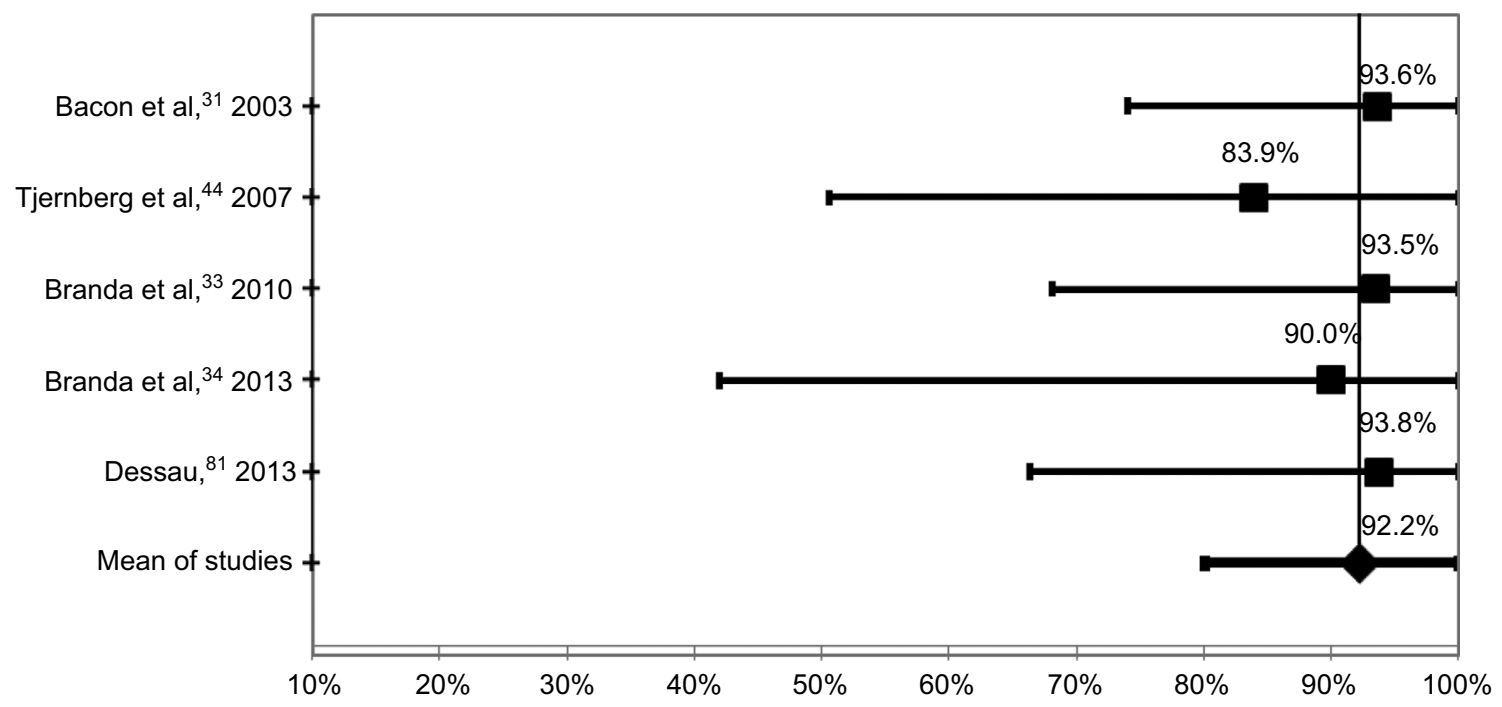

Figure 8 Sensitivity for neurological/arthritis/carditis samples. 
the need to diagnose and treat LB if an EM rash is present, usually giving specific instructions that serology tests are not necessary. ${ }^{23,24,79}$ Two studies gave details of length of time between EM rash onset and sample extraction/testing. Marangoni et $\mathrm{al}^{38}$ indicate that patients enrolled in the study had a duration of EM rash ranging from 5 to 106 days with a mean of 16 days. However, only the mean sensitivity of $60.1 \%$ (95\% confidence interval 38.6\%-84.4\%) with testing carried out at enrollment was presented. Wormser et $\mathrm{al}^{47}$ gave details of the "days postonset of symptoms"; however, the sensitivity data presented did not show sensitivity versus postonset time, and only overall averages were shown. The sensitivity achieved with a history of an EM rash using a synthetic C6 peptide ELISA and WB test in a two-tier protocol was 34.5\%, for a false-negative rate of $65.5 \%$.

There was no evidence that the commercial test kit sensitivity has improved significantly over time. Linear regression of data from all included studies is shown in Figure 9, which demonstrates an increase in test sensitivity of $4 \%$ points over the 20 -year study period. These results lend support to the recently published conclusion of Stricker and Johnson ${ }^{14}$ to the effect that "FDA-cleared commercial serological testing for Lyme disease is inadequate for the diagnosis of the disease".

\section{Conclusion}

All studies included in this analysis used test samples that were predefined as positive for LB infection either by a prior serological test that was positive, or a clinical record showing a history of an EM rash, or culture confirmed, or a combination of these. Based on this, the sensitivity determined for the tests with these samples would be expected to be close to $100 \%$. This is not the case, as has been demonstrated in this analysis.

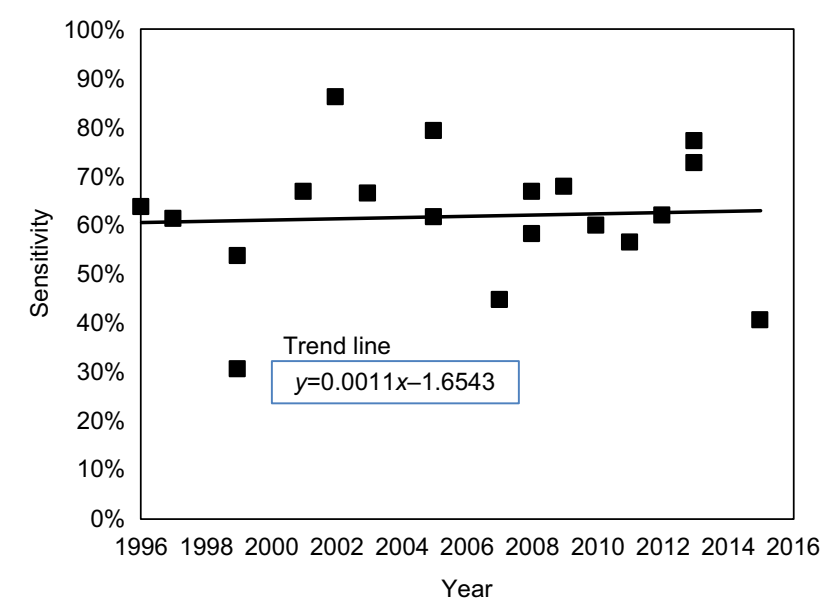

Figure 9 Test sensitivity versus year of publication.
The sensitivity of an individual test was as low as $7.4 \%$. The mean sensitivity of all test kits with all samples was $59.5 \%$, and ranged from $30.6 \%$ to $86.2 \%$.

The technologies with the highest sensitivity were WB, with a mean sensitivity of all test kits of $62.4 \%$, and ELISA at $62.3 \%$. The mean of tests using the synthetic C6 peptide ELISA was $53.9 \%$, followed by the two-tier methodology with a sensitivity of $53.7 \%$.

There was a lack of standardization of disease "stages" and of the definition of early and late disease. Along with the potential for bias in sample categorization, the sensitivity of the tests presented for disease stages should be considered as indicative and not definitive. The studies do demonstrate that sensitivity increases with severity of symptoms and dissemination to joints, the heart, and the central nervous system.

The sensitivities achieved by these studies do not represent test performance in clinical settings. The methods for selection of samples used in these studies eliminated samples from patients demonstrating a weak antibody response. Also, clinical samples will include those taken soon after infection before antibodies have developed; those from patients already treated with antibiotics or steroids, which suppress antibody production and depress test sensitivity; and those from patients with weakened immune systems. Quantification of the impact on test sensitivity was not possible since no data were presented by the individual study authors for the effects of any of these variables. Additional issues include quality control practices of testing facilities used by clinicians and issues such as sample shipment and storage. Currently, there are 21 named species assigned to the LB group, of which nine are proven or suspected pathogens, and other Borrelia species that generate Lyme-like symptoms such as B. miyamotoi. It was not possible to determine from the studies identified in this analysis, nor from other sources, the sensitivity of commercial test kits when patient samples were infected by species other than B. burgdorferi sensu stricto, B. afzelii, or $B$. garinii. It is recommended that studies be carried out to determine test sensitivities for other species and improved test methods actively pursued and approved for general use.

An important clinical implication of our conclusion that current Lyme testing lacks sensitivity is that many genuine cases of LB may be underdiagnosed. Based on the findings of our meta-analysis, we would recommend that clinicians do not assume that negative laboratory investigation results exclude a diagnosis of Lyme disease.

\section{Acknowledgment}

The first author (MJC) was diagnosed with Lyme disease in 2009 . 


\section{Disclosure}

The authors have no financial competing interests and report no conflicts of interest in this work.

\section{References}

1. Wright DJM. Borrel's accidental legacy. Clin Microbiol Infect. 2009;15(5):397-399.

2. Cutler SJ, Ruzic-Sabljic E, Potkonjak A. Emerging borreliae - Expanding beyond Lyme borreliosis. Mol Cell Probes. 2016.

3. Cook MJ. Lyme borreliosis: a review of data on transmission time after tick attachment. Int J Gen Med. 2015;8:1-8. Available from: http://www. ncbi.nlm.nih.gov/pubmed/25565881. Accessed November 5, 2016.

4. Leeflang M, Ang C, Berkhout J, et al. The diagnostic accuracy of serological tests for Lyme borreliosis: a systematic review and metaanalysis. BMC Infect Dis. 2016;16(140):1-17.

5. Pritt BS, Mead PS, Johnson DK, et al. Identification of a novel pathogenic Borrelia species causing Lyme borreliosis with unusually high spirochaetaemia: a descriptive study. Lancet Infect Dis. 2016;16:556-564.

6. Liveris D, Schwartz I, Bittker S, et al. Improving the yield of blood cultures from patients with early lyme disease. J Clin Microbiol. 2011;49(6):2166-2168.

7. Saidac DS, Marras SA, Parveen N. Detection and quantification of Lyme spirochetes using sensitive and specific molecular beacon probes. $B M C$ Microbiol. 2009;9:43.

8. Liang FT, Steere AC, Marques AR, Johnson BJ, Miller JN, Philipp MT. Sensitive and specific serodiagnosis of Lyme disease by enzyme-linked immunosorbent assay with a peptide based on an immunodominant conserved region of Borrelia burgdorferi vlsE. J Clin Microbiol. 1999;37(12):3990-3996. Available from: http://www.pubmedcentral. nih.gov/articlerender.fcgi?artid=85863\&tool=pmcentre $\&$ rendertype $=$ abstract. Accessed November 5, 2016.

9. Barth C, Straubinger RK, Krupka I, Müller E, Sauter-Louis C, Hartmann K. Comparison of different diagnostic assays for the detection of Borrelia burgdorferi-specific antibodies in dogs. Vet Clin Pathol. 2014;43(4):496-504.

10. Towbin H, Staehelin T, Gordon J. Electrophoretic transfer of proteins from polyacrylamide gels to nitrocellulose sheets: procedure and some applications. 1979. Biotechnology. 1992;24:145-149. Available from: http://www.ncbi.nlm.nih.gov/pubmed/1422008. Accessed September 10, 2016.

11. Towbin H, Staehelin T, Gordon J. Electrophoretic transfer of proteins from polyacrylamide gels to nitrocellulose sheets: procedure and some applications. Proc Natl Acad Sci U S A. 1979;76(9):4350-4354. Available from: http://www.ncbi.nlm.nih.gov/pubmed/388439. Accessed November 5, 2016.

12. Tylewska-Wierzbanowska SS, Chmielewski T. Limitation of serological testing for Lyme borreliosis: evaluation of ELISA and western blot in comparison with PCR and culture methods. Wien Klin Wochenschr. 2002;114(13-14):601-605. Available from: http://www.ncbi.nlm.nih. gov/pubmed/12422608. Accessed January 27, 2011.

13. Trinity Biotech. EU-Lyme IgM Western Blot Western Blot Test System for the Detection of IgM Antibodies to Borrelia Afzelii " $P K O$ " and Borrelia garinii REF 44-2020M.; 2010. Available from: http://www. trinitybiotech.com/Product Documents/44-2020M-29 EN EU Lyme IgM WB Test System.pd.

14. Stricker RB, Johnson L. Lyme disease: the promise of Big Data, companion diagnostics and precision medicine. Infect Drug Resist. 2016;9:215-219.

15. Kurien BT, Scofield RH. Western blotting. Methods. 2006;38(4):283-293.

16. Collares-Pereira M, Couceiro S, Franca I, et al. First isolation of Borrelia lusitaniae from a human patient. J Clin Microbiol. 2004;42(3):1316-1318.

17. Golovchenko M, Vancová M, Clark K, Oliver JH, Grubhoffer L, Rudenko N. A divergent spirochete strain isolated from a resident of the southeastern United States was identified by multilocus sequence typing as Borrelia bissettii. Parasit Vectors. 2016;9(68):1-5.
18. Rudenko N, Golovchenko M, Mokráček A, et al. Detection of Borrelia bissettii in cardiac valve tissue of a patient with endocarditis and aortic valve stenosis in the Czech Republic. J Clin Microbiol. 2008;46(10):3540-3543. Available from: http://www.pubmedcentral. nih.gov/articlerender.fcgi?artid=2566110\&tool=pmcentrez\&renderty pe $=$ abstract. Accessed November 5, 2016.

19. Stanek G, Reiter M. The expanding Lyme Borrelia complex-clinical significance of genomic species? Clin Microbiol Infect. 2011;17:487493. Available from: http://www.ncbi.nlm.nih.gov/pubmed/21414082. Accessed November 5, 2016.

20. Venclíková K, Betášová L, Sikutová S, Jedličková P, Hubálek Z, Rudolf I. Human pathogenic borreliae in Ixodes ricinus ticks in natural and urban ecosystem (Czech Republic). Acta Parasitol. 2014;59(4):717-720.

21. Mavin S, Milner RM, Evans R, Chatterton JM, Joss AW, Ho-Yen DO. The use of local isolates in Western blots improves serological diagnosis of Lyme disease in Scotland. J Med Microbiol. 2007;56(Pt 1): $47-51$.

22. Association of State and Territorial Public Health Laboratory Directors. Proceedings of the Second National Conference on Serologic Diagnosis of Lyme Disease, Dearborn, Michigan, 27-29 October 1994:1-111. Washington, DC.

23. Wormser GP, Dattwyler RJ, Shapiro ED, et al. The clinical assessment, treatment, and prevention of lyme disease, human granulocytic anaplasmosis, and babesiosis: clinical practice guidelines by the Infectious Diseases Society of America. Clin Infect Dis. 2006;43(9):1089-1134.

24. British Infection Association. The epidemiology, prevention, investigation and treatment of Lyme borreliosis in United Kingdom patients: a position statement by the British Infection Association. $J$ Infect. 2011;62(5):329-338.

25. Baehr R, Berghoff W, Everth U, et al. Diagnosis and Treatment of Lyme Borreliosis (Lyme Disease) Guidelines of the German Borreliosis Society Deutsche Borreliose-Gesellschaft e.V. Jena, Germany; 2010. Available from: http://www.borreliose-gesellschaft.de/Texte/guidelines. pdf. Accessed November 6, 2016.

26. Mullis KB, Faloona FA. Specific synthesis of DNA in vitro via a polymerase-catalyzed chain reaction. Methods Enzymol. 1987;155:335-350. Available from: http://www.sciencedirect.com/science/article/pii/ 0076687987550236. Accessed September 10, 2016.

27. Mullis K, Faloona F, Scharf S, Saiki R, Horn G, Erlich H Specific enzymatic amplification of DNA in vitro: the polymerase chain reaction. Cold Spring Harb. 1986;51(Pt 1):263-273. Available from: http:// symposium.cshlp.org/content/51/263.extract. Accessed September 10, 2016.

28. Puri BK, Segal DR, Monro JA. Diagnostic use of the lymphocyte transformation test-memory lymphocyte immunostimulation assay in confirming active Lyme borreliosis in clinically and serologically ambiguous cases. Int J Clin Exp Med. 2014;7(12):5890-5892.

29. Neyeloff JL, Fuchs SC, Moreira LB. Meta-analyses and Forest plots using a microsoft excel spreadsheet: step-by-step guide focusing on descriptive data analysis. BMC Res Notes. 2012;5(1):52.

30. Centers for Disease Control and Prevention. Lyme Disease (Borrelia burgdorferi) 2011 Case Definition. National Notifiable Diseases Surveillance System (NNDSS); 2011. Available from: https://wwwn.cdc. gov/nndss/conditions/lyme-disease/case-definition/2011/. Accessed October 13, 2016.

31. Bacon RM, Biggerstaff BJ, Schriefer ME, et al. Serodiagnosis of Lyme disease by kinetic enzyme-linked immunosorbent assay using recombinant VlsE1 or peptide antigens of Borrelia burgdorferi compared with 2-tiered testing using whole-cell lysates. J Infect Dis. 2003;187(8):1187-1199.

32. Binnicker MJ, Jespersen DJ, Harring JA, Rollins LO, Bryant SC, Beito EM. Evaluation of two commercial systems for automated processing, reading, and interpretation of Lyme borreliosis Western blots. $J$ Clin Microbiol. 2008;46(7):2216-2221.

33. Branda JA, Aguero-Rosenfeld ME, Ferraro MJ, Johnson BJ, Wormser GP, Steere AC. 2-tiered antibody testing for early and late Lyme disease using only an immunoglobulin $\mathrm{G}$ blot with the addition of a VlsE band as the second-tier test. Clin Infect Dis. 2010;50(1):20-26. 
34. Branda JA, Strle F, Strle K, Sikand N, Ferraro MJ, Steere AC. Performance of United States serologic assays in the diagnosis of lyme borreliosis acquired in Europe. Clin Infect Dis. 2013;57:333-340.

35. Gomes-Solecki MJ, Wormser GP, Schriefer M, et al. Recombinant assay for serodiagnosis of Lyme Disease regardless of OspA vaccination status. J Clin Microbiol. 2002;40(1):193-197.

36. Goossens HA, van den Bogaard AE, Nohlmans MK. Evaluation of fifteen commercially available serological tests for diagnosis of Lyme borreliosis. Eur J Clin Microbiol Infect Dis. 1999;18(8):551-560. Available from: http://www.ncbi.nlm.nih.gov/pubmed/10517192. Accessed November 5, 2016.

37. Klempner MS, Schmid $\mathrm{CH}, \mathrm{Hu} \mathrm{L}$, et al. Intralaboratory reliability of serologic and urine testing. Am J Med. 2001;110(3):217-219.

38. Marangoni A, Sparacino M, Cavrini F, et al. Comparative evaluation of three different ELISA methods for the diagnosis of early culture-confirmed Lyme disease in Italy. J Med Microbiol. 2005;54(Pt 4):361-367.

39. Marangoni A, Moroni A, Accardo S, Cevenini R. Borrelia burgdorferi VlsE antigen for the serological diagnosis of Lyme borreliosis. Eur $J$ Clin Microbiol Infect Dis. 2008;27(5):349-354.

40. Mogilyansky E, Loa CC, Adelson ME, Mordechai E, Tilton RC. Comparison of Western Immunoblotting and the C6 Lyme antibody test for laboratory detection of Lyme Disease. Clin diagnositic Lab Immunol. 2004;11(5):924-929.

41. Porwancher RB, Hagerty CG, Fan J, et al. Multiplex immunoassay for Lyme disease using VlsE1-IgG and pepC10-IgM antibodies: improving test performance through bioinformatics. Clin Vaccine Immunol. 2011;18(5):851-859

42. Smit PW, Kurkela S, Kuusi M, Vapalahti O. Evaluation of two commercially available rapid diagnostic tests for Lyme borreliosis. Eur J Clin Microbiol Infect Dis. 2015;34(1):109-113. Available from: http://www. ncbi.nlm.nih.gov/pubmed/25073771. Accessed November 5, 2016.

43. Tilton RC, Sand MN, Manak M. The western immunoblot for Lyme disease: determination of sensitivity, specificity, and interpretive criteria with use of commercially available performance panels. Clin Infect Dis. 1997;25(Suppl 1):S31-S34. Available from: http://www.ncbi.nlm.nih. gov/pubmed/9233661. Accessed November 5, 2016.

44. Tjernberg I, Krüger G, Eliasson I. C6 peptide ELISA test in the serodiagnosis of Lyme borreliosis in Sweden. Eur J Clin Microbiol Infect Dis. 2007;26(1):37-42.

45. Trevejo RT, Krause PJ, Sikand VK, et al. Evaluation of two-test serodiagnostic method for early Lyme disease in clinical practice. J Infect Dis. 1999;179(4):931-938.

46. Vermeersch P, Resseler S, Nackers E, Lagrou K. The C6 Lyme antibody test has low sensitivity for antibody detection in cerebrospinal fluid. Diagn Microbiol Infect Dis. 2009;64(3):347-349.

47. Wormser G, Schriefier M, Aquero-Rosenfeld ME. Single-tier testing withh the C6 peptide ELISA kit compared with two-tier testing for Lyme disease. Diagn Microbiol Infect Dis. 2012;75:9-15.

48. Ang CW, Notermans DW, Hommes M, Simoons-Smit AM, Herremans $\mathrm{T}$. Large differences between test strategies for the detection of anti-Borrelia antibodies are revealed by comparing eight ELISAs and five immunoblots. Eur J Clin Microbiol Infect Dis. 2011;30(8): 1027-1032.

49. Burbelo PD, Issa AT, Ching KH, Cohen JI, Iadarola MJ, Marques A. Rapid, simple, quantitative, and highly sensitive antibody detection for lyme disease. Clin Vaccine Immunol. 2010;17(6):904-909.

50. Busson L, Reynders M, Van den Wijngaert S, et al. Evaluation of commercial screening tests and blot assays for the diagnosis of Lyme borreliosis. Diagn Microbiol Infect Dis. 2012.

51. Coulter P, Lema C, Flayhart D, et al. Two-Year Evaluation of Borrelia burgdorferi culture and supplemental tests for definitive diagnosis of Lyme Disease. J Clin Microbiol. 2005;43(10):5080-5084.

52. Craven RB, Quan TJ, Bailey RE, et al. Improved serodiagnostic testing for Lyme disease: results of a multicenter serologic evaluation. Emerg Infect Dis. 1996;2(2):136-140. Available from: http://www.pubmedcentral.nih.gov/articlerender.fcgi? $\operatorname{artid}=2639820 \&$ tool $=$ pmcentrez\&r endertype $=$ abstract. Accessed November 5, 2016.
53. Dessau RB, Bangsborg JM,EjlertsenT, Skarphedinsson S, SchonheyderHC. Utilization of serology for the diagnosis of suspected Lyme borreliosis in Denmark: Survey of patients seen in general practice. BMC Infect Dis. 2010;10(1):317.

54. Engstrom SM, Shoop E, Johnson RC. Immunoblot interpretation criteria for serodiagnosis of early Lyme disease. J Clin Microbiol. 1995;33(2):419427. Available from: http://www.pubmedcentral.nih.gov/articlerender. fcgi? artid $=227960 \&$ tool $=$ pmcentrez $\&$ rendertype $=$ abstract. Accessed November 5, 2016.

55. Eshoo MW, Crowder CC, Rebman AW, et al. Direct molecular detection and genotyping of Borrelia burgdorferi from whole blood of patients with early Lyme Disease. PLoS One. 2012;7(5):e36825.

56. Goettner G, Schulte-Spechtel U, Hillermann R, Liegl G, Wilske B, Fingerle V. Improvement of Lyme borreliosis serodiagnosis by a newly developed recombinant immunoglobulin $\mathrm{G}$ (IgG) and IgM line immunoblot assay and addition of VlsE and DbpA homologues. J Clin Microbiol. 2005;43(8):3602-3609. http://www.pubmedcentral.nih.gov/articlerender. fcgi? artid=1233984\&tool=pmcentrez\&rendertype=abstract. Accessed November 5, 2016.

57. Gomes-Solecki MJ, Wormser GP, Persing DH, et al. A first-tier rapid assay for the serodiagnosis of Borrelia burgdorferi infection. Arch Intern Med. 2001;161(16):2015-2020. Available from: http://www.ncbi.nlm. nih.gov/pubmed/11525704. Accessed January 11, 2015.

58. Heikkilä T, Huppertz HI, Seppälä I, Sillanpää H, Saxen H, Lahdenne P. Recombinant or peptide antigens in the serology of Lyme arthritis in children. J Infect Dis. 2003;187(12):1888-1894.

59. Koidl C, Riedl R, Fett S, Schweighofer B, Waitzl B, Marth E. Performance of two screening and two confirmation assays for detection of IgM and IgG antibodies to Borrelia burgdorferi sensu lato in a routine diagnostic laboratory. ECCMID. 2013;65:95.

60. Liang FT, Aberer E, Cinco M, et al. Antigenic conservation of an immunodominant invariable region of the VlsE lipoprotein among European pathogenic genospecies of Borrelia burgdorferi sl. J Infect Dis. 2000;182(5):1455-1462.

61. Lawrenz MB, Hardham JM, Owens RT, et al. Human antibody responses to VlsE antigenic variation protein of Borrelia burgdorferi. J Clin Microbiol. 1999;37(12):3997-4004. Available from: http://www. pubmedcentral.nih.gov/articlerender.fcgi? artid=85865\&tool=pmcentre z\&rendertype=abstract. Accessed November 5, 2016.

62. Liu ZY, Hao Q, Hou XX, et al. A Study of the technique of Western blot for diagnosis of lyme disease caused by Borrelia afzelii in China. Biomed Environ Sci. 2013;26(3):190-200.

63. Nordberg M, Forsberg P, Nyman D, et al. Can ELISPOT be applied to a clinical setting as a diagnostic utility for Neuroborreliosis? Cells. 2012;1(4):153-167.

64. Nowakowski J, Schwartz I, Liveris D, et al. Laboratory diagnostic techniques for patients with early Lyme disease associated with erythema migrans: a comparison of different techniques. Clin Infect Dis. 2001;33:2023-2027. Available from: http://www.jstor.org/pss/4482944. Accessed September 19, 2011.

65. Rebman AW, Crowder LA, Kirkpatrick A, Aucott JN. Characteristics of seroconversion and implications for diagnosis of post-treatment Lyme disease syndrome: acute and convalescent serology among a prospective cohort of early Lyme disease patients. Clin Rheumatol. 2015;34(3):585-589.

66. Robertson J, Guy E, Andrews N, et al. A European multicenter study of immunoblotting in serodiagnosis of lyme borreliosis. J Clin Microbiol. 2000;38(6):2097-2102. Available from: http:/www.pubmedcentral.nih. gov/articlerender.fcgi?artid=86736\&tool=pmcentrez\&rendertype=abstract. Accessed November 5, 2016.

67. Ryffel K, Péter O, Rutti B, Suard A, Dayer E. Scored antibody reactivity determined by immunoblotting shows an association between clinical manifestations and presence of Borrelia burgdorferi sensu stricto, B. garinii, B. afzelii, and B. valaisiana in humans. J Clin Microbiol. 1999;37(12):4086-4092. Available from: http://www.pubmedcentral. nih.gov/articlerender.fcgi?artid=85886\&tool=pmcentrez\&rendertype =abstract. Accessed November 5, 2016. 
68. Schulte-Spechtel U, Lehnert G, Liegl G, et al. Significant improvement of the recombinant Borrelia-specific immunoglobulin $\mathrm{G}$ immunoblot test by addition of VlsE and a DbpA homologue derived from Borrelia garinii for diagnosis of early neuroborreliosis. J Clin Microbiol. 2003;41(3):1299-1303. Available from: http://www.pubmedcentral.nih. gov/articlerender.fcgi?artid $=150259 \&$ tool $=$ pmcentrez\&rendertype $=a b$ stract. Accessed November 5, 2016.

69. Seriburi V, Ndukwe N, Chang Z, Cox ME, Wormser GP. High frequency of false positive IgM immunoblots for Borrelia burgdorferi in clinical practice. Clin Microbiol Infect. 2012;18(12):1236-1240.

70. Skarpaas T, Ljøstad U, Søbye M, Mygland A. Sensitivity and specificity of a commercial C6 peptide enzyme immuno assay in diagnosis of acute Lyme neuroborreliosis. Eur J Clin Microbiol Infect Dis. 2007; 26(9):675-677.

71. Skogman BH, Croner S, Forsberg P, et al. Improved laboratory diagnostics of Lyme neuroborreliosis in children by detection of antibodies to new antigens in cerebrospinal fluid. Pediatr Infect Dis $J$. 2008;27(7):605-612.

72. Smismans A, Goossens VJ, Nulens E, Bruggeman CA. Comparison of five different immunoassays for the detection of Borrelia burgdorferi IgM and IgG antibodies. Clin Microbiol Infect. 2006;12(7):648-655.

73. Steere AC, McHugh G, Damle N, Sikand VK. Prospective study of serologic tests for lyme disease. Clin Infect Dis. 2008;47(2):188-195.

74. Wormser GP, Liveris D, Hanincová K, et al. Effect of Borrelia burgdorferi genotype on the sensitivity of $\mathrm{C} 6$ and 2-tier testing in North American patients with culture-confirmed Lyme disease. Clin Infect Dis. 2008;47(7):910-914.
75. Zhioua E, Rodhain F, Binet P, Perez-Eid C. Prevalence of antibodies to Borrelia burgdorferi in forestry workers of Ile de France, France. Eur J Epidemiol. 1997;13(8):959-962.

76. Lindgren E, Jaenson TGT. Lyme borreliosis in Europe : influences of climate and climate change, epidemiology, ecology and adaptation measures. In: Menne B, Ebi KL, editors. World Health. Denmark, Europe: World Health Organization; 2006;EU/04/5046. http://www.euro.who. int/_data/assets/pdf_file/0006/96819/E89522.pdf.

77. Robertson JN, Gray JS, MacDonald S, Johnson H. Seroprevalence of Borrelia burgdorferi sensu lato infection in blood donors and park rangers in relation to local habitat. Zentralbl Bakteriol. 1998;288(2):293-301. Available from: http://www.sciencedirect.com/science/article/pii/ S0934884098800534. Accessed November 5, 2016.

78. Tomao P, Ciceroni L, D’Ovidio MC, et al. Prevalence and incidence of antibodies to Borrelia burgdorferi and to tick-borne encephalitis virus in agricultural and forestry workers from Tuscany, Italy. Eur J Clin Microbiol Infect Dis. 2005;24(7):457-463.

79. Stanek G, Fingerle V, Hunfeld KP, et al. Lyme borreliosis: clinical case definitions for diagnosis and management in Europe. Clin Microbiol Infect. 2011;17(1):69-79.

80. Johnson BJ, Robbins KE, Bailey RE, et al. Serodiagnosis of Lyme Disease: accuracy of a two-step approach using a flagella-based ELISA and immunoblotting. J Infect Dis. 1996;174(2):346-353.

81. Dessau RB. Diagnostic accuracy and comparison of two assays for Borrelia-specific IgG and IgM antibodies: proposals for statistical evaluation methods, cut-off values and standardization. J Med Microbiol. 2013;62(Pt 12):1835-1844.
International Journal of General Medicine

\section{Publish your work in this journal}

The International Journal of General Medicine is an international, peer-reviewed open-access journal that focuses on general and internal medicine, pathogenesis, epidemiology, diagnosis, monitoring and treatment protocols. The journal is characterized by the rapid reporting of reviews, original research and clinical studies across all disease areas.

\section{Dovepress}

The manuscript management system is completely online and includes a very quick and fair peer-review system, which is all easy to use. Visit http://www.dovepress.com/testimonials.php to read real quotes from published authors. 